\title{
The determinants of the antibiotic resistance process
}

\author{
Beatriz Espinosa Franco' \\ Marina Altagracia Martínez ${ }^{2}$ \\ Martha A Sánchez Rodríguez' \\ Albert I Wertheimer ${ }^{3}$ \\ 'Facultad de Estudios Superiores \\ Zaragoza (UNAM), Mexico; ${ }^{2}$ Universidad \\ Autónoma Metropolitana Unidad \\ Xochimilco, Mexico; ${ }^{3}$ Temple University, \\ Philadelphia, Pennsylvania, USA
}

Correspondence: Beatriz Espinosa Franco Calle 39 \# I 32, Colonia Ignacio Zaragoza, Mexico DF, Mexico, cp 15000

Tel +525556030535

Email beatrizef@prodigy.net.mx
Background: The use of antibiotic drugs triggers a complex interaction involving many biological, sociological, and psychological determinants. Resistance to antibiotics is a serious worldwide problem which is increasing and has implications for morbidity, mortality, and health care both in hospitals and in the community.

Objectives: To analyze current research on the determinants of antibiotic resistance and comprehensively review the main factors in the process of resistance in order to aid our understanding and assessment of this problem.

Methods: We conducted a MedLine search using the key words "determinants", "antibiotic", and "antibiotic resistance" to identify publications between 1995 and 2007 on the determinants of antibiotic resistance. Publications that did not address the determinants of antibiotic resistance were excluded.

Results: The process and determinants of antibiotic resistance are described, beginning with the development of antibiotics, resistance and the mechanisms of resistance, sociocultural determinants of resistance, the consequences of antibiotic resistance, and alternative measures proposed to combat antibiotic resistance.

Conclusions: Analysis of the published literature identified the main determinants of antibiotic resistance as irrational use of antibiotics in humans and animal species, insufficient patient education when antibiotics are prescribed, lack of guidelines for treatment and control of infections, lack of scientific information for physicians on the rational use of antibiotics, and lack of official government policy on the rational use of antibiotics in public and private hospitals.

Keywords: antibiotic drug resistance, determinants, social-biological

\section{Introduction}

Resistance to a variety of antibiotics is an important phenomenon that has been the subject of many scientific meetings during the past decade. Resistance has become a serious public health problem around the world and there are no indications that it is abating. It includes pathogenic agents that utilize different mechanisms and channels of drug resistance in different countries. ${ }^{1,2}$

Recent debate on the problem has focused on the inappropriate use of antibiotics worldwide. ${ }^{2,3}$ This practice fosters conditions that favor multiplication of resistant microorganisms while at the same time suppressing susceptible forms. ${ }^{4}$ Antibiotic resistance can represent an enormous cost to a patient and to the health care system. When the appropriate antibiotic is not applied, the process of infection is not interrupted, which can lead to serious consequences. , $^{5,6}$

Resistance can arise from the use of antibiotics, antimalarial drugs, and pesticides. Each beneficial application of these treatments increases the likelihood that they will be less effective both for the intended target and for other targets when used in the future. In this way the use of these drugs triggers a complex interaction involving many biological, sociological, and psychological determinants. ${ }^{7,8}$ 
At least three interdependent variables are involved in antibiotic overuse. Patients expect to be prescribed antibiotics for any infection, often simply for any febrile condition. Physicians, for their part, fear uncontrolled infection. Antibiotics provide a false sense of security when they are prescribed before or without undertaking a complete diagnosis. Thirdly, many countries allow antibiotics to be purchased over the counter without a medical prescription. ${ }^{9}$

Differences in location, population demographics, and office police towards pharmaceutical representatives and sampling are also potentially important covariates for the overuse of antibiotics. Two studies in Mexico found that self-medication of Rx drugs accounted for $42 \%$ of all the $\mathrm{Rx}$ consumed during the studies period and antibiotic alone accounted for $20.1 \%$. ${ }^{10,11}$

Access to cheaper or free antibiotic agents, like generic drugs, has been also associated with overuse of antibiotic especially in the developing countries as well as promotion of free generic antibiotic samples in developed countries. ${ }^{12}$ Recently, Conklin and colleagues acknowledge that many infections, including acute upper respiratory tract infections do not require initiation of any antibiotic therapy, and that the convenient presence of some type of promotion like "kiosks" could potentially have promoted the overuse of antibiotics for clinically inappropriate indications. ${ }^{13-15}$

During the past 10 to 15 years, antibiotic-resistant organisms have increased steadily, and currently represent a threat to the treatment of illness, to the point where no antibiotics are available to treat some life-threatening infections. ${ }^{16-18}$ An increase in research on infection control and interventions to improve patient safety can be expected during the coming 20 years. ${ }^{19}$

The use of antibiotics to treat bacterial illnesses in animals and plants increased throughout the twentieth century. For example, antibiotics became an important element in commercial animal production for their favorable effect on growth when added to feed in subtherapeutic quantities. ${ }^{20}$

We all share the blame for the development of antibiotic resistance, including governments, universities, professional associations, the pharmaceutical and chemical industries, health care professionals, and consumers, who regard drugs as a quick and easy answer to conditions that actually require in-depth responses from individuals and society. ${ }^{3}$ Although resistance has been developing gradually over many years, it seems inexplicable that the medical community has not acted earlier.

The purpose of our review was to analyze the current situation on the determinants of antibiotic resistance, and comprehensively review the main factors in the process of resistance in order to improve the understanding of this issue.

\section{Methods}

We conducted a MedLine search using the key words "determinants", "antibiotic", and "antibiotic resistance" to identify publications between 1995 and 2007 on the determinants of antibiotic resistance. Publications that did not address the determinants of antibiotic resistance were excluded.

\section{Results}

The process and determinants of antibiotic resistance can be described as follows:

\section{Discovery and development of antibiotics}

Antibiotics are among the most important achievements of the twentieth century. Although some effective treatments used long ago contained antibiotic chemicals, their use in general was limited to certain illnesses.

Antibiotics are defined as substances produced by microorganisms (bacteria, fungi, actinomycetes), which suppress the proliferation of other (pathogenic) microorganisms and can eventually destroy these. The term "antibiotics" now includes synthetic antibacterials such as the sulfonamides and quinolones, which are not actually synthesized by microbes. Different antibiotics have quite different physical, chemical, and pharmacological properties, as well as different antibacterial spectra and mechanisms of action. ${ }^{21}$

Early in the twentieth century, infectious and parasitic diseases were the major causes of human morbidity and mortality, especially among infants and children. ${ }^{22}$ The golden age of antibiotic treatments was ushered in by the discovery and subsequent development of penicillin from the filtrate of a fungus Penicillium notatum culture by Alexander Fleming in 1929. Another key development in the modern history of antibiotics was the synthesis in 1935 by Gerhard Domagk of the first sulfonamide, prontosil, which was spectacularly effective against streptococcus infections. . $, 17,23-30^{-30}$

The success of these two antibiotics stimulated a search for further antibiotic substances. In 1944, the work of Selman Waksman in a soil microbiology laboratory led to the isolation of streptomycin from a soil actinobacterium. Streptomycin was the first antibiotic remedy against Mycobacterium tuberculosis, the main cause of tuberculosis, as well as many Gram-negative bacteria. Since that time, a great quantity of research, much of it undertaken by pharmaceutical companies, has yielded many useful drugs. ${ }^{9,31}$ 
During the past 20 years, approval of new antibiotics has decreased. Some 50 antibiotics have been developed, and large pharmaceutical companies have provided everimproved new generations of antibiotics. At the same time, the importance of infectious diseases in public health has decreased, and pharmaceutical research has focused increasingly on treatments for chronic diseases. ${ }^{5,32}$

The fundamental predicament is that antibiotics are a nonrenewable source, because the length of time they are beneficial and available appears to have a biological limit, something which is not the case with other treatments. Few antibiotics and/or antifungals are currently being developed, in comparison with investment in research and development of antivirals. ${ }^{6}$

The main reason that the industry has moved away from antibiotic research and development is that the investment can no longer be recovered rapidly, partly because of increased regulatory conditions and strict price controls imposed by many governments. . $^{17,20,33}$

The useful lifetime of current and future antibiotics could depend on the speed with which resistance develops, which in turn depends on the usage model, not only in humans but also in agriculture and horticulture. ${ }^{34}$

Recent worldwide development of methicillin-resistant Staphylococcus aureus (MRSA) in the community has stimulated the development of new antibiotics. The new developments of antibiotic are summarized in Table 1 as well as the new agent brand names and active principle, antibiotic class, antimicrobial activity, country, and date of approval.

Resistance to teicoplanin $\left(\right.$ Targocid $^{\circledR}$ ), a first-generation glycopeptide, has emerged because of its similarity to other glycopeptides, which has motivated research aimed at developing new antibiotics. ${ }^{35,36}$

Streptogramins are a combination of quinupristin and dalfopristin $\left(\right.$ Synercid $\left.^{\circledR}\right)$. An oral streptogramin, pristinamycin in combination with doxycycline, is used in Europe to treat MRSA infections but is not available in the US. ${ }^{33,35,37,38}$

Second-generation glycopeptides are dalbavancin, telavancin, and oritavancin. The use of these drugs should be limited to treatment of Gram-positive multidrugresistant bacterial infections. ${ }^{33,35,38-40}$ Telavancin was superior to standard therapy for microbiologic eradication in patients with $S$. aureus infection (92\% versus 78\%) and in patients with MRSA. Currently, telavancin is under investigation (phase II). ${ }^{41}$

Daptomycin $\left(\right.$ Cubicin $\left.^{\circledR}\right)$ has been shown to be effective in the treatment of skin and soft tissue infections, and bacteremia with right-sided endocarditis, but efficacy has not been demonstrated for pneumonia as a result of binding with pulmonary surfactants. ${ }^{33,35,42}$

Tigecycline $\left(\right.$ Tygacil $\left.^{\circledR}\right)$ is a bacteriostatic agent which is most effective in complicated skin and soft tissue infections, as well as hospital-acquired and community-acquired intra-abdominal infections. . $33,35,43,44$

Linezolid $\left(\right.$ Zyvox $\left.^{\circledR}\right)$ is recommended for pneumonia caused by drug-resistant $S$. pneumoniae complicated by skin and soft tissue infections and for diabetic foot infections. It is indicated for the treatment of catheter-related bloodstream infections or catheter-site infections. Unfortunately, the number of reports of resistance and therapeutic failure associated with linezolid has been increasing since $2005.33,35,36,45$

The Food and Drug Administration (FDA) updated the labeling for the antibiotic telithromycin $\left(\operatorname{Ketek}^{\circledR}\right)$ to improve its safe use of by patients; the changes include the removal of two of the three previously approved indications - acute bacterial sinusitis and acute bacterial exacerbations of chronic bronchitis - from the drug's label. The FDA approved "a boxed warning" that states that telithromycin is contraindicated in patients with myasthenia gravis. In addition, warnings were strengthened for specific drug-related adverse events like visual disturbances and loss of consciousness and visual disturbances and hepatotoxicity. Telithromycin is marketed and used extensively in many other countries, including Japan and countries in Europe. ${ }^{33,35,38,46}$

Ertapenem $\left(\right.$ Invanz $\left.{ }^{\circledR}\right)$ is recommended for complicated intra-abdominal infections, community acquired pneumonia, complicated skin and skin structure infections, complicated urinary tract infections including pyelonephritis. Ertapenem resistance has recently appeared. ${ }^{33,47}$

Doripenem $\left(\right.$ Doribax $\left.^{\circledR}\right)$ shows improved stability against beta-lactamases. The US FDA has approved new indications for doripenem. ${ }^{33,48}$

Faropenem in dosage form (oral only) reduced activity against MRSA, but is not likely to be used as a first-line therapy for invasive, multidrug-resistant $S$. aureus infections. Faropenem medoxomil (formerly faropenenm daloxate) is an oral prodrug that has been evaluated as a therapy for community-acquired respiratory tract infections. ${ }^{41,49}$

The new antibiotic, iclaprim, is a diaminopyrimidine, selective dihydrofolate inhibitor. It is currently undergoing phase III clinical trials for treating skin and skin structure infections. ${ }^{39-41}$

The pharmaceutical industry still lacks strategies for developing novel antibiotics. Only two new classes of antibiotics of novel mechanisms of action (linezolid and daptomycin) have been introduced into the market during the last 
Table I Development of new antibiotics during the last three decades

\begin{tabular}{|c|c|c|c|}
\hline $\begin{array}{l}\text { Antibiotic agent, brand } \\
\text { and active and principal names }\end{array}$ & Antibiotic class & Antimicrobial activity & Country and date of approval \\
\hline $\begin{array}{l}\text { Quinupristin and dalfopristin } \\
\left(\text { Synercid }^{\circledR}\right) \text { I.V. }\end{array}$ & Streptogramins & $\begin{array}{l}\text { Infections associated with vancomycin- } \\
\text { resistant Enterococcus faecium bacteremia }\end{array}$ & US, September 2I, 1999. ${ }^{33,35,37,38}$ \\
\hline $\begin{array}{l}\text { Dalbavancin, telavancin, } \\
\text { oritavancin }\end{array}$ & $\begin{array}{l}\text { Second-generation } \\
\text { glycopeptides }\end{array}$ & $\begin{array}{l}\text { Bactericidal activity against MRSA,VRSA, } \\
\text { vancomycin-resistant enterococcus and } \\
\text { drug-resistant Streptococcus pneumoniae }\end{array}$ & US, phase II, 2009.33,35,38-40 \\
\hline Daptomycin $\left(\right.$ Cubicin $^{\circledast}$ ) I.V. & $\begin{array}{l}\text { Cyclic lipopeptide } \\
\text { (new class of antibiotic) }\end{array}$ & $\begin{array}{l}\text { Bactericidal activity against Gram-positive } \\
\text { S. aureus, MRSA, Staphylococcus epidermidis } \\
\text { including methicillin-resistant S. epidermidis, } \\
\text { vancomycin-resistant enterococcus, } \\
\text { penicillin-resistant S. pneumoniae and } \\
\text { Streptococcus pyogenes }\end{array}$ & US, December 9, 2003..$^{33,35,42}$ \\
\hline Tigecycline $\left(\right.$ Tygaci $\left.^{\circledR}\right)$ I.V. & $\begin{array}{l}\text { Glycylcycline similar } \\
\text { to the tetracyclines }\end{array}$ & $\begin{array}{l}\text { Bacteriostatic activity against Gram-positive, } \\
\text { Gram-negative and atypical anaerobic } \\
\text { bacteria, and antibiotic-resistant, MRSA, } \\
\text { vancomycin-resistant enterococcus, } \\
\text { penicillin-resistant S. pneumoniae }\end{array}$ & US, June, $2005 .^{33,35,43,44}$ \\
\hline $\begin{array}{l}\text { Linezolid }\left(Z y v^{\circledR}{ }^{\circledR}\right) \text { Oral } \\
\text { and parenteral forms }\end{array}$ & Oxazolidinone & $\begin{array}{l}\text { Bacteriostatic activity against enterococci and } \\
\text { staphylococci, bactericidal activity against many } \\
\text { drug-resistant streptococci, S. pneumoniae } \\
\text { and infections caused by anaerobic bacteria }\end{array}$ & US, April I8, 2000. $33,35,36,45$ \\
\hline Telithromycin $\left(\right.$ Ketek $\left.^{\circledR}\right)$ & $\begin{array}{l}\text { Erythromycin } \\
\text { derivative }\end{array}$ & $\begin{array}{l}\text { The FDA announced changes, including } \\
\text { the removal of two of the three previ- } \\
\text { ously approved indications - acute bacterial } \\
\text { sinusitis and acute bacterial exacerbations } \\
\text { of chronic bronchitis. Ketek is now indicated } \\
\text { for the treatment of community-acquired } \\
\text { pneumoniae (of mild to moderate severity) } \\
\text { due to Streptococcus pneumoniae, (including } \\
\text { multi-drug resistant isolates), Haemophilus } \\
\text { influenzae, Moxarella catarrhalis, Chlamydophila } \\
\text { pneumoniae, or Mycoplasma pneumoniae }\end{array}$ & $\begin{array}{l}\text { US, April 0I, 2004.33,35,36,38,46 } \\
\text { Last published revision: } \\
\text { February I2, } 2007\end{array}$ \\
\hline $\begin{array}{l}\text { Ertapenem }\left(\text { Invanz }{ }^{\circledR}\right) \\
\text { I.V. }^{\text {a }} \text { and intramuscular }\end{array}$ & Carbapenem & $\begin{array}{l}\text { Activity against Gram-positive and } \\
\text { Gram-negative bacteria, but shows only } \\
\text { limited activity against Enterococcus } \\
\text { aspp., Pseudomonas aeruginosa and other } \\
\text { nonfermenting Gram-positive bacteria }\end{array}$ & US, November 2I, 200I. ${ }^{33,47}$ \\
\hline Doripenem (Doribax ${ }^{\circledR}$ ) I.V. ${ }^{a}$ & Carbapenem & $\begin{array}{l}\text { Bactericidal activity, for the treatment } \\
\text { of complicated urinary tract and } \\
\text { intra-abdominal infections }\end{array}$ & US, October I2, 2007.33,48 \\
\hline Faropenem Oral & Carbapenem & $\begin{array}{l}\text { It was developed for the treatment of } \\
\text { community-acquired respiratory tract } \\
\text { infections and later for uncomplicated skin } \\
\text { and skin structure infections. It was shown } \\
\text { to be active against penicillin-resistant } \\
\text { S. pneumoniae and } \beta \text {-lactamase-producing } \\
\text { H. influenzae and M. catarrhalis }\end{array}$ & Not yet FDA approved, 2008. ${ }^{41,49}$ \\
\hline Ceftobiprole $\left(\right.$ Zeftera $\left.^{\circledR}\right)$ & Cephalosporine & $\begin{array}{l}\text { Bactericidal activity is mainly active against } \\
\text { Gram-positive pathogens. For the treatment } \\
\text { of complicated skin and soft tissue infections } \\
\text { and nosocomial pneumonia caused by } \\
\text { MRSA }^{b} \text {, enterococci and S. pneumoniae }\end{array}$ & US, phase III, 2009. ${ }^{33,35,40}$ \\
\hline Iclaprim & $\begin{array}{l}\text { Diaminopyrimidine } \\
\text { New antibiotic }\end{array}$ & $\begin{array}{l}\text { It has demonstrated in vitro activity against } \\
\text { S. aureus, including } \text { MRSA }^{b} \text {. Iclaprim was also } \\
\text { active against one strain of VRSA }\end{array}$ & US, phase III, 2009.39.4I \\
\hline
\end{tabular}

Abbreviations: IV, intravenous presentation; MRSA, methicillin-resistant S. aureus; VRSA, vancomycin-resistant S. aureus. 
three decades. ${ }^{50,51}$ Many of the new antibiotics are chemical modifications of existing drugs and are rapidly overtaken by bacteria in the environment. ${ }^{35}$ Recently, there were new achievements in researching new essential bacterial genes, potential targets for antibacterial drugs, and application of metagenomics strategy. ${ }^{50}$

\section{Antibiotic resistance}

Antibiotic resistance would seem to be an inevitable consequence of the use of antibiotics. It was described for the first time in the 1940s, and found in a $\beta$-lactamase-producing strain of $S$. aureus. ${ }^{21,52,53}$

The rapid development of resistance in bacteria and viruses is an evolutionary response to the selective pressure of antibiotics and results from natural selection. It is accepted that microbiological adaptation evolves, and that the main reason for the development of antibiotic resistance is the widespread use of antibiotics. . $^{7,29,54-58}$

Antibiotics have been called miracle drugs, but 60 years of use, underuse, and overuse have resulted in increasingly frequent resistance in a growing number of antibiotic-bacteria combinations. Resistance rates are quite variable, depending on context and environment. . $^{55,59-61}$

The first resistant strains appeared in hospitals, but rapidly spread to the community and are continuing to spread around the world. Resistant microorganisms recognize no geographical borders. ${ }^{30}$

Many pathogenic agents have become resistant to various different classes of antibiotic drugs since the 1960s. This fact has become clinically, epidemiologically and socioeconomically important, because infections caused by resistant microorganisms can be especially difficult and costly to treat. ${ }^{1}$

\section{Mechanisms of antibiotic resistance}

The evolution of resistance falls into two categories: a) molecular redundancy: Organisms adapt their physiology to new environments after receiving a signal to change their physiological state. The signal usually arrives from the new environment. The change in physiological state occurs uniformly when the new environment is not lethal to the organism. b) Molecular infidelity: Cells under stress are more receptive to foreign DNA; in addition, cells under certain forms of stress have high mutation rates. ${ }^{29}$

Bacteria are highly adaptable organisms with a remarkable ability to mutate in response to their environment. Bacteria that survive the effects of an antibiotic are more adaptable, and subsequently develop resistant gene or genome mutations.
These genetically altered bacteria multiply to produce a population resistant to the antibiotic, and can also transfer their new resistance-carrying genes to other bacterial species through the process of conjugation. Certain antibiotics have mutagenic activity, which can speed up the development of resistance. . $^{7,35,55-62}$

Multiple resistant genes which are resistant to different antibiotics with the same chemical structure are often found in the same plasmid or transposon. If the drug mechanism is similar, bacteria resistant to one member of the group will also be resistant to the others. ${ }^{61,63-70}$

Bacteria can be resistant to an antibiotic for any of several reasons: 1) the drug does not reach its objective; 2) the drug is deactivated; or 3 ) the target is altered. Some bacteria produce enzymes on the surface of the cell or within the cell, which inactivate the antibiotic substance, whether by hydrolysis, acetylation, phosphorylation or adenylation. ${ }^{38}$

Others have impermeable membranes that resist penetration by the drug. Bacteria lacking these ducts or channels may be resistant to hydrophilic antibiotics. Others lack the transport systems needed for the drug to penetrate into the bacteria. ${ }^{21}$

A recent report suggests that airborne intercellular communication between isolated bacterial colonies may induce resistance. ${ }^{56,71,72}$

\section{Determinants of resistance}

Several broad influences on antibiotic decision-making can be identified, which help to explain the different resistance rates: ${ }^{6,73}$

- The first is the behavior of the antibiotic prescriber, that is, the physician, physician extender, or nurse practitioner. Physicians differ in their choice, use and prescribed dose of antibiotics.

- The second is patient demand, according to different attitudes to health care.

- Thirdly, macro-level influences on prescribing antibiotics, include in particular, sociocultural, economic, and health care regulatory policy factors. Cultural factors may help to determine which signs and symptoms are perceived as abnormal, and require medical care and drug treatments. Health care practitioners must be persuaded that the primary determinant of patient satisfaction is not a prescription for an antibiotic, but rather effective communication about their illness.

- Fourthly, some others determinants of antibiotic resistance not less important are dosing variation and use of poor pharmacodynamic principles among others. ${ }^{74-77}$ 
A number of Canadian and American studies have suggested that antibiotic prescribers may be influenced by such characteristics as where they received their medical training, years in practice, hospital affiliation, and type of practice (private or public hospital). ${ }^{16,72}$ Burke noted that inappropriate prophylactic use of antibiotics for surgical patients is common. Unwarranted, prolonged preoperational antibiotic prophylaxis increases resistance to antibiotic drugs. ${ }^{6,78}$ Some important errors include delayed antibiotic administration, excessive duration and the use of inappropriate agents. ${ }^{73}$ Although the chain of causality is not clear, selection of resistant bacteria has been promoted by multiple courses of antibiotics, first-line treatment with broad spectrum antibiotics, long duration antibiotic treatment, and antibiotic treatment of viral infections of the respiratory tract. When clinicians are not sure whether an infection is bacterial, they tend to prescribe antibiotics. There is a wide variation in antibiotic prescription patterns within and between different cities within a given country. ${ }^{61,79-84}$

Antibiotics are also over-prescribed in ambulatory care, especially for respiratory tract infections. ${ }^{85}$ When primary care physicians are asked their reasons for prescribing antibiotics for upper respiratory tract infections, they cite clinical factors (duration of the illness, probability of poor results) and nonclinical factors (patient satisfaction, time savings for the clinic). The physician's practice style can be correlated with duration of the visit and whether an antibiotic is prescribed; physicians with shorter visit times are more likely to prescribe antibiotics. ${ }^{86}$

At the same time, some studies suggest that more than half of antibiotic prescriptions are inappropriate. ${ }^{87,88}$ In Mexico, recent studies have documented that between $60 \%$ to $80 \%$ of the patients were with upper respiratory tract infections received inappropriate prescriptions of antibiotics. ${ }^{12}$

Physicians resist changing their behavior, and maintaining antibiotic prescription models against patient or family member pressure represents a particular challenge. ${ }^{16,19,57,89,91}$ One study suggests that patients want an antibiotic because of a mistaken belief that it is the best treatment for pain. ${ }^{92}$

On the second broad influence, patient demand, we find that treatment compliance depends on the characteristics of the patient, the illness, and social and family environment, and on the health care system and health care professionals, including physicians and pharmacists. In addition, other factors such as patient age, sex, ethnicity, level of education, economic level, hygiene, and community facilities all affect the appropriateness of the treatment and patient compliance. ${ }^{61,93}$ People use antibiotics with excessive familiarity, lack of concern, and confidence; they self-medicate because antibiotics are available without professional control; and patients believe that antibiotics are more effective than any other types of medicines. ${ }^{62,89,94}$ In some countries, including in developed countries, antibiotics are freely available and can be bought without a prescription (even if this is prohibited by law) at sidewalk stands from vendors who know little or nothing about dosage, indications, or contraindications. ${ }^{22,95,96}$

When antibiotics are used incorrectly - for too short a time, at too low a dose, too low a frequency, or for the wrong illness - bacteria and other microorganisms are more likely to adapt and replicate rather than die. ${ }^{90}$

Furthermore, an association has been found between the patient's lack of participation in the physician visit and the patient's poor understanding of the medications prescribed. ${ }^{80}$

Macro-level determinants include overcrowding, poor sanitation, and a lack of observance of recommended sanitary procedures, so that propagation of pathogenic bacterial agents is increased, leading to increasing illness rates, thus creating a greater need for antibiotic use. ${ }^{4}$ Antibiotic use is also influenced by the interaction between the knowledge and expectations of prescriber and patient, economic incentives, and characteristics of the health care system and the regulatory system. ${ }^{90}$ The key determinant is related to government policy on hospital financing. ${ }^{16}$

The cultural context of antibiotic use also plays an important role. Expectations of medical care are affected by the patient's socioeconomic status; patient satisfaction has been observed to decrease slightly with increased income. ${ }^{97}$ In Hungary, lower socioeconomic status has been found to be a determinant in antibiotic use. ${ }^{98}$

A particularly disturbing aspect of the growth of resistance is the long term addition of antibiotics, at subtherapeutic concentrations, to food and water and as growth promoters in animal feed, such as poultry feed. ${ }^{99,100}$ Some resistant bacteria found in animals are transmitted to humans, mainly in meat and other foods of animal origin, or through direct contact with animals as they are being raised, which may have serious consequences for children and the elderly. ${ }^{20,55,101,102}$

Studies in different cities in the UK and US have shown an association between the use of antibiotics in animal feed and antibiotic resistance. ${ }^{20,102}$

In the twentieth century, the use of antibiotics to treat bacterial illnesses in animals-including fish-and plants also increased. At least 17 classes of antibiotic agents have been approved as growth promoters in the US. These include tetracyclines, penicillins, macrolides, lincomycin (a clindamycin analog), and virginiamycin. The precise number of antibiotic agents used in agriculture is unknown. ${ }^{63,101-103}$ 
Transfer of resistant bacteria from animal feed to humans is most evident in human pathogenic bacteria that have animal feed sources, such as Campylobacter, of which chickens and ducks are a reservoir, and Salmonella, found in chicken, pigs, cattle, and ducks. Campylobacter species cause mild to moderate infections and occasionally severe infections, especially in children, the elderly, and immunocompromised persons. A 1999 University of Iowa study found multidrugresistant and cephalosporin-resistant human, porcine, and bovine Salmonella isolates in the same geographic region. Although there is much heterogeneity between animal feed, meat, poultry and human samples, they do provide evidence of the spread of gentamicin-resistant enterococci from animals to humans through food. ${ }^{55,61}$

Antibiotics have also been used extensively for treatment and prevention of bacterial diseases in crops, fruit trees, and ornamental plants. ${ }^{61}$ In 1996, 300,000 pounds of streptomycin and oxytetracycline were aerosolized to treat apples and pears prophylactically against infections. ${ }^{34}$

Ingestion of substandard, counterfeit or inadequately stored antibiotics or of subtherapeutic doses leads to ineffective or incomplete treatment which increases the selective pressure on resistant strains. Metabolites and excess drug are excreted, and can enter the environment through inadequately treated waste or unhygienic sanitary conditions. The most direct route by which antibiotics from human waste enter rivers is through wastewater treatment outflows. Hospitals may also send antibiotics and resistant bacteria to landfills, from which they enter the water. These antibiotics are nonbiodegradable whether in sediment or in water. ${ }^{65,103,104}$

Paradoxically, chlorination of drinking water and wastewater substantially raises the proportions of antibioticresistant bacteria even though it reduces initial counts. ${ }^{104}$

Some antibiotics are completely stable in liquid, and some are tolerant to heat. For example, small quantities of neomycin in egg are quite tolerant to normal cooking processes. ${ }^{61}$

Compounds such as household disinfectants and other antibacterial agents can also influence antibiotic resistance. The increase in the use of these agents has caused dramatic changes in environmental flora, because of antibiotic resistance. ${ }^{61}$

A thorough consideration of the theory of evolution and the microorganism theory of infectious diseases leads to the conclusion that excessive use of antibiotics in any ecological niche will produce harmful effects on human health in the same niche, as well as in niches nearby and farther away. ${ }^{105}$

The last group of determinants of antibiotic resistance is related to dosing variations and the use of poor pharmacodynamic principles. One of the later approaches of antimicrobial resistance separates genetic resistance into types: acquired and de novo. Acquired resistance involves genes system that move into pathogen population and external source and de novo resistance often develops in a gradual, stepwise manner, usually from the accumulation of mutation that individually lower susceptibility by modest increments. In principle, blocking the growth of mutants subpopulations should lead to resistance more rapidly than ones that do not even though the regimens may equally effective at curing disease. The problem is to identify mutant-prone regimens prior to widespread clinical use. ${ }^{74-77}$

The mutant selection window is antimicrobial concentration range extending from the minimal concentration required to block the growth of wild-type bacteria up to that required to inhibit the growth of the least susceptible, single-step mutant. Since window dimensions are characteristic of each pathogen-antimicrobial combination, they can be linked with antimicrobial pharmacokinetics to rank compounds and dosing regimens in terms of their propensity to enrich mutant fractions of bacterial populations. The described theory suggests that for situations in which antimicrobial concentrations cannot be kept above window, restricting the enrichment mutants requires combination therapy. It might provide a rationale for deciding whether a compound (antibiotic) should be administered as part of a combination regimen rather than being used alone. The described hypothesis is still awaiting in vivo validation. ${ }^{74-77}$

\section{Consequences of antibiotic resistance}

Among the US population of more than 300 million Americans, there are 160 million antibiotic prescriptions for a total of 23 million $\mathrm{kg}$ of antibiotics per year. In 1992, $18 \%$ of the total antibacterial medicines prescribed in the US were for respiratory illnesses. $S$. pneumoniae is resistant to various drugs. ${ }^{62,106}$

Resistance to penicillin, cephalosporins and other $\beta$-lactam antibiotics has increased the use of erythromycin and new macrolides such as azithromycin and clarithromycin. ${ }^{106}$ For this reason bacterial infections resistant to antibiotics are becoming increasingly common in clinical settings. ${ }^{107}$

Some countries have already given official recognition to the effects of increasing bacterial antibiotic resistance on public health. Bacterial antibiotic resistance is a serious problem worldwide, with implications for morbidity, mortality and health care in hospitals and in the community. ${ }^{34,64,103,107,108}$ An association has been demonstrated between initially inappropriate antibiotic treatments and increased mortality, because resistant organisms are more difficult to treat and almost impossible to eradicate 
in some patients. ${ }^{104}$ For this reason, there is growing concern that resistant organisms might arise that cannot be effectively treated with available antibiotic therapies. ${ }^{103}$

Research has been shown that resistance often leads to a delay in the administration of a microbiologically effective therapy, a chain of events which has been associated with detrimental outcomes. The majority of published studies have shown an association between antibiotic resistance and adverse results in the order of a 1.3 to 2 times increase in mortality, morbidity, and costs for patient with resistant infections, compared with susceptible infections. ${ }^{31,109}$

Individuals receiving antibiotics at therapeutic doses undergo changes in their normal intestinal, upper respiratory and genitourinary flora. In some cases a superadded infection may arise as a result of these changes. The broader the effect of an antibiotic, the more it alters the normal microflora, and the greater the probability that a single microorganism will predominate, invade the host and produce infection. ${ }^{21}$ Hospital-acquired infections are not only difficult to treat, but also significantly delay the patient's discharge from hospital and significantly increase the cost of treatment. Moreover, when the patient is discharged from hospital, health care workers and visitors may become carriers facilitating the spread of resistant microorganisms to the community. ${ }^{104,110}$

Another problem related to antibiotic resistance is the enormous cost to the patient and the health care system. In the US the annual cost of treating antibiotic-resistant infections has been calculated at more than US\$4 billion. ${ }^{103}$

As drug-resistance to older, and in general cheaper, antibiotics becomes more common, a newer, more expensive, broad spectrum drug or combination therapy may be required. The prescriber's concern about antibiotic resistance may however lead to an empirical choice of newer, more potent drugs or combinations of drugs for fear that a delay in waiting to identify the bacteria and assess its sensitivity might increase morbidity or mortality. ${ }^{105}$ These agents are usually more expensive, and people with lower incomes can afford them even less. The newer drugs are also more likely to have harmful effects on protective microflora and may even be toxic or less effective. ${ }^{31,109}$

In fact, studies in the medical literature have shown conclusively that patients infected with drug-resistant organisms are more likely to require hospitalization, to have a longer hospital stay, and have an increased probability of dying. ${ }^{5}$

Other consequences for patients that must be considered include the long term effects on future health of having a resistant infection, increased time off work, being way from family due to longer hospitalization and subsequent recuperation, and the emotional effects of having a resistant infection. ${ }^{59}$

\section{Alternatives to antibiotic resistance}

The indiscriminate use of antibiotics to treat diseases in humans, and their increasing use in the agricultural industry are important points. As already mentioned, up to $50 \%$ of antibiotic use in humans may be questionable and up to $80 \%$ of agricultural use may be unnecessary. ${ }^{68}$

The incidence of multidrug-resistant pathogenic bacteria is on the rise. More than $70 \%$ of the bacterial species that cause these infections are likely to be resistant to at least one commonly used antibiotic. ${ }^{58}$ This trend will continue as long as the resistance problem remains unchecked. There are some actions that are widely agreed to be essential areas of general consensus for recommended action. $7,20,73,85,90,94,110-119$ Local governments should establish policies for the elaboration of national and regional guidelines for infection control based on surveillance data on resistance and reinforce the general health laws in the dispensing of antibiotics at all levels as well as eliminate financial incentives that promote misuse of antibiotics.

The promotion of communication between government, academic institutions, and the pharmaceutical industry should be reinforced and mutual collaboration must be promoted. Academic institutions should periodically and systematically evaluate health-related curriculums for continuing education for veterinarians, physicians, physician extenders, pharmacists, and nurses to ensure that rational use of antibiotics is taught.

Health institutions should systematically and continually evaluate antibiotic prescriptions to ensure the rational use of antibiotics. Continuing education programs about the rational use of antibiotic for all health professional should be institutionalized. Among physicians, health institution policies should include the prudent promotion of antibiotics prescribing; promote improvements in hygiene; improve patient care; promote appropriate treatment selection; identify pathogens and resistant pathogens.

Hospitals should establish infection control committees, drug therapy committees, guidelines for appropriate use of antibiotics based on evidence; produce pharmacy reports based on defined daily doses; establish a list of essential drugs; educate staff about problems related to antibiotics use.

Community pharmacies should avoid the practice of "prescribing" (particularly in developing countries) and dispensing antibiotic without medical prescriptions. ${ }^{12}$

Physicians and pharmacists should discuss with patients the proper use of antibiotics and the individual and environmental consequences of their misuse. 
Veterinarians should minimize antibiotic use in animals, work to improve hygiene on farms, and use other alternatives to promote animal growth. Local governments should regulate antibiotic prescribing in animals and their use in soils; restrict the use of antibiotics as growth promoters; reduce the need for prophylactic and therapeutic use of antibiotics; improve vaccination programs and farm hygiene.

All local governments, health care and academic institutions, health professionals and individuals should work together to improve antibiotic resistance surveillance through local surveillance networks; recruit participants to the networks; support reference laboratories and the World Health Organization programs; monitor resistance in food animals; and monitor human populations.

Research projects at all levels should include risk-benefit analysis of the use of growth promotants, environmental impacts, and processing and distribution methods for food.

In the pharmaceutical industry, increased research and development on new and cost-effective antibiotics is needed. More research has to be done on the measurement and potential use of mutant selection window. ${ }^{74-77}$

\section{Conclusions}

Analysis of the published literature showed that the main determinants of antibiotic resistance are irrational use of antibiotic drugs in humans and animal species, insufficient patient education when antibiotics are prescribed, lack of guidelines for treatment and control of infection in hospitals, lack of awareness and relevant scientific information for physicians prescribing antibiotics, and lack of official government policy on the rational use of antibiotics in the public and private sectors. It is therefore necessary that every country take proper measures to control these determinants in order to check antibiotic resistance.

\section{Disclosure}

The authors report no conflicts of interest in this work.

\section{References}

1. Grupo Colaborativo Resist Net. La resistencia a los antibióticos en América Latina: importancia de los programas Artemio y Resist Net. In: Salvatierra-González R, Benguigui Y, editors. Resistencia antimicrobiana en las Américas: Magnitud del problema y su contención. Washington, DC: OPS/OMS; 2000. p. 39-53.

2. Sader HS, Jones RN. Resistencia a los antimicrobianos de los agentes patógenos causantes de infecciones nosocomiales y comunitarias en América Latina: reseña general de las estadísticas de 1997. In: Salvatierra-González R, Benguigui Y, editors. Resistencia antimicrobiana en las Américas: Magnitud del problema y su contención. Washington, DC: OPS/OMS; 2000. p. 54-73.

3. Fefer E. Uso racional de medicamentos: políticas, reglamentación y normas regionales. In: Salvatierra-González R, Benguigui Y, editors. Resistencia antimicrobiana en las Américas: Magnitud del problema y su contención. Washington, DC: OPS/OMS; 2000. p. 211-219.
4. Murray BE. Problemas y dificultades para controlar el uso de antibióticos. In: Salvatierra-González R, Benguigui Y, editors. Resistencia antimicrobiana en las Américas: Magnitud del problema y su contención. Washington, DC: OPS/OMS; 2000. p. 220-227.

5. Almeida FN. For a general theory of health: preliminary epistemological and anthropological notes. Cad Saúde Pública, Rio de Janeiro. 2001;17(4):753-799.

6. Rodríguez RS. Consumo de antimicrobianos en el hospital: costos y consecuencias del uso y abuso. In: Salvatierra-González R, Benguigui Y, editors. Resistencia antimicrobiana en las Américas: Magnitud del problema y su contención. Washington, DC: OPS/OMS; 2000. p. 246-257.

7. Overbye KM, Barrett JF. Antibiotics: where did we go wrong? DDT. 2005;10(1):45-52.

8. Harbarth S, Samore MH. Antimicrobial resistance determinants and future control. Emerg Infect Dis. 2005;11(6):794-801.

9. Laxminarayan R, Brown GM. Economics of antibiotic resistance: a theory of optimal use. J Environ Econ Manage. 2001;42:183-206.

10. Vázquez-Moreno E, Moreno-Santamaría R, Altagracia-Martínez M, Kravzov-Jinich J, Ríos-Castañeda C. Self-medication in the Mexican State of Veracruz. J Pharm Finance, Economics and Policy. 2004;13(2):45-63.

11. Altagracia-Martínez M, Kravzov-Jinich J, Moreno-Santamaría R, Ríos-Castañeda C, Vázquez-Moreno E. Automedicación en comunidades rural y urbanas del Estado de Guerrero, México. Revista Mexicana de Ciencias Farmacéuticas. 2003;34(2):27-35.

12. Dreser A, Wirtz VJ, Corbett KK, Echániz G. Uso de antibióticos en México: revisión de problemas y políticas. Salud Pública Méx. 2008;50(4):480-487.

13. Kogut SJ, Spooner LM. Resistance to in-office dispensing of generic antibiotic samples. J Manag Care Pharm. 2009;15(1):62-65.

14. Conklin MH, Culley EJ, O'Donnell J. Case study of the effects of officebased generic drug sampling on antibiotic drug costs and first-line antibiotic prescribing ratios. J Manag Care Pharm. 2009;15(1):55-61.

15. Scott AB, Culley EJ, O’Donnell J. Effects of a physician office generic drug sampling system on generic dispensing ratios and drug costs in a large managed care organization. J Manag Care Pharm. 2007;13(5):412-419.

16. Zhang Y, Harvey K. Rational antibiotic use in China: lessons learnt through introducing surgeons to Australian guidelines. Aust New Zealand Health Policy. 2006;3(5):1-6.

17. Norrby SR, Nord CE, Finch Roger. Lack of development of new antimicrobial drugs: a potential serious threat to public health. Lancet Infect Dis. 2005;5:115-119.

18. Cosgrove SE, Carmeli Y. The impact of antimicrobial resistance on health and economic outcomes. Clin Infect Dis. 2003;36(1):1433-1437.

19. Larson E, Lin SX, Gomez-Duarte C. Antibiotic use in Hispanic households, New York City. Emerg Infect Dis. 2003;9(9):1096-1102.

20. Use of antimicrobials outside human medicine and resultant antimicrobial resistance in humans. World Health Organization. 2002 [cited 2005 Aug 24]; 268: [about 4 p.]. Available from: http://www. who.int/mediacentre/factsheets/fs268/en/print.html.

21. Hardman JG, Limbird LE, Molinoff PB, Ruddon RW, Goodman GA, editors. Las bases farmacológicas de la terapéutica. 9th ed. México, DF: McGraw-Hill Interamericana; 2000. p. 1095-1121.

22. Salvatierra-González R, Benguigui Y. Resistencia antimicrobiana en las Américas: Magnitud del problema y su contención. Washington, DC: OPS/OMS; 2000. p. vii-xi.

23. Tortora JG. Microbiology: an introduction. 7th ed. Redwood City, CA: The Benjamín Cummin Publishing Company; 2001. p. 491-509.

24. Stuart TW. Microbiología. 6a ed. Madrid, Spain: McGraw-Hill Interamericana; 2000. p. 79-111.

25. Black GJ. Microbiology principles and applications. 6th ed. New Jersey, Upper Saddle River, NJ: Prentice Hall; 2004. p. 356-372.

26. Ingraham JL, Ingraham CA. Introducción a la microbiología. 2nd ed. Barcelona, Spain: Reverté; 2002. p. 486-513.

27. Joklik KW, Willett PH, Amos B. Microbiología Zinsser. 20th ed. Buenos Aires, Argentina: Editorial Médica Panamericana; 1998. p. 219-228. 
28. Romero CR. Microbiología y parasitología humana. 2nd ed. México, DF: Editorial Médica Panamericana; 1996. p. 40-50.

29. Heinemann JA. How antibiotics cause antibiotic resistance. DDT. 1999;4:72-79.

30. Kunin CM. Resistance to antimicrobial drugs-a worldwide calamity. Ann Inter Medic. 1993;118(7):557-561.

31. McCormick JB. Epidemiology of emerging/re-emerging antimicrobialresistant bacterial pathogens. Curr Opin Microbiol. 1998;1:125-129.

32. MacDougall C, Polk RE. Antimicrobial stewardship programs in health care systems. Clin Microbiol Rev. 2005;18(4):638-656.

33. Barie PS, Dellinger EP, Ellner JJ, McGowan JE. Maximizing nosocomial infection management with newer therapeutic approaches and techniques in an era of increasing microbial resistance: a surgical perspective. 2007; [cited 2007 Sept 22]; [about 15 p.]. Available from: http://www.medscape.com/viewprogram/7566_pnt.

34. Walsh C. Antibiotics: actions, origins, resistance. Washington, DC: ASM Press; 2003. p. 3-20, 285-295.

35. Capriotti T. Resistant "superbugs" create need for novel antibiotics. Dermatol Nurs. 2007;19(1):65-70.

36. Lopez LP, Li JZ, Balan DA, et al. Hospital resource use and cost of treatment with linezolid versus teicoplanin for treatment of serious gram-positive bacterial infection among hospitalized patients from South America and Mexico: results from a multicenter trial. Clin Ther. 2003;25(6):1846-1871

37. Final labeling. Synercid ${ }^{\circledR}$ I.V. [cited 2008 Jun 18]; [about 16 p.]. Available from: http://www.fda.gov/cder/foi/label/2008/ 050748s008,050747s0081bl.pdf.

38. Wright GD. Mechanisms of resistance to antibiotics. Curr Opin Chem Biol. 2003;7:563-569.

39. Appelbaum PC, Jacobs MR. Recently approved and investigational antibiotics for treatment of severe infections, caused by Gram-positive bacteria. Curr Opin Microbiol. 2005;8:510-517.

40. Food and Drug Administration. Index to Drug-Specific Information. 2009 [cited 2009 Feb 18] Available from: http://www.fda.gov/cder/ drug/DrugSafety/DrugIndex.htm.

41. Drew RH. Emerging options for treatment of invasive, multidrugresistant Staphylococcus aureus infections. Pharmacotherapy. 2007;27(2):227-249.

42. Final labeling. Daptomycin $\left(\right.$ Cubicin $\left.^{\circledR}\right)$ I.V. [cited 2003 Dec 13]; [about 1 p.]. Available from: http://www.fda.gov/cder/drug/InfoSheets/patient/ daptomycinPIS.htm.

43. Final labeling. Tigecycline $\left(\right.$ Tygacil $\left.^{\mathbb{\circledR}}\right)$ I.V. [cited 2005 July 27]; [about 1 p.]. Available from: http://www.fda.gov/cder/drug/InfoSheets/patient/ tigecyclinePIS.htm

44. Rasmussen BA, Gluzman Y, Tally FP. Inhibition of protein synthesis occurring on tetracycline-resistant, TetM-protected ribosomes by a novel class of tetracyclines, the glycylcyclines. Antimicrob Agents Chemother. 1994;38(7):1658-1660.

45. FDA alert, Linezolid $\left(Z_{y v o x}{ }^{\mathbb{B}}\right)$. Information. [cited 2007 Mar 16]; [about 1 p.]. Available from: http://www.fda.gov/cder/drug/infopage/ linezolid/default.htm.

46. Telithromycin (Ketek $\left.{ }^{\circledR}\right)$. Information. [cited 2007 Feb 12]; [about 1 p.]. Available from: http://www.fda.gov/cder/drug/infopage/telithromycin/ default.htm.

47. Application number: 21-337. Ertapenem (Invanz ${ }^{\mathbb{R}}$ ) I.V. or I.M. [cited 2001 Nov 21]; [about 1 p.]. Available from: http:/www.fda.gov/cder/ foi/nda/2001/21337_Invanz_prntlbl.pdf.

48. FDA approves new drug to treat complicated urinary tract and intraabdominal infections. [cited 2007 Oct 17]; [about 1 p]. Available from: http://www.fda.gov/bbs/topics/NEWS/2007/NEW01728.html.

49. Critchley IA, Brown SD, Traczewski MM, Tillotson GS, Janjic N. National and regional assessment of antimicrobial resistance among community - acquired respiratory tract pathogens identified in a 2005-2006 US faropenem surveillance study. Antimicrob Agents Chemother. 2007;51(12):4382-4389.

50. Jagusztyn-Krynicka EK, Wyszyńska A. The decline of antibiotic era-new approaches for antibacterial drug discovery. Pol J Microbiol. 2008;57(2):91-98.
51. Ertapenem (INVANZ)-A new parenteral carbapenem. The Medical Letter. 2002;44(W1126A):25-26.

52. Levy SB. Factors impacting on the problem of antibiotic resistance. J Antimicrob Chemother. 2002;49(1):25-30.

53. World Health Organization (WHO). Drug resistance threatens to reverse medical progress. Press Release WHO/41.2000; [cited 2005 Aug 24]; [about 4 p.]. Available from: http://www.essentialdrugs.org/efarmacos/ archive/200011/msg00040.php.

54. Colgan R, Powers JH. Appropriate antimicrobial prescribing: approaches that limit antibiotic resistance. Am Fam Physician. 2001;64(6):999-1004.

55. Andersson DI. Persistence of antibiotic resistant bacteria. Curr Opini Microbiol. 2003;6:452-456.

56. Mckeegan KS, Borges-Walmsley MI, Walmsley AR. Microbial and viral drug resistance mechanisms. Trends Microbiol. 2002;10(10):S8-S14.

57. Cantrell R, Young AF, Martin BC. Antibiotic prescribing in ambulatory care settings for adults with colds, upper respiratory tract infections, and bronchitis. Clin Ther. 2002;24(1):170-182.

58. Cassell GH. Emergent antibiotic resistance: health risks and economic impact. FEMS Immunol Med Microbiol. 1997;18:271-274.

59. Lipsitch M. The rise and fall of antimicrobial resistance. Trends Microbiol. 2001;9(9):438-442.

60. Wise R, Hart T, Cars O, et al. Antimicrobial resistance. BMJ. 1998; 317(7159):609-610.

61. Barbosa TM, Levy SB. The impact of antibiotic use on resistance development and persistence. Drug Resist Updat. 2000;3:303-311.

62. Jacobs MR. Streptococcus pneumoniae: Epidemiology and patterns of resistance. Am J Med. 2004;117(3A):3S-15S.

63. Bergoglio RM. Antibióticos. 5th ed. Buenos Aires, Argentina: Editorial Médica Panamericana; 1993. p. 3-95.

64. Mascaretti OA. Bacteria versus antibacterial agents an integrated approach. Washington, DC: ASM Press; 2003. p. 87-95.

65. Rooklidge SJ. Environmental antimicrobial contamination from terraccumulation and diffuse pollution pathways. Sci Total Environ. 2004;325:1-13.

66. Koneman EW, Allen SD, Janda WM, Schreckenberger PC, Winn WC. Diagnóstico Microbiológico. 5th ed. Buenos Aires, Argentina: Editorial Panamericana; 1999. p. 764-832.

67. Whittle G, Shoemaker NB, Salyers AA. The role of bacteroides conjugative transposons in the dissemination of antibiotic resistance genes. Cell Mol Life Sci. 2002;9(12):2044-2054.

68. Poole K. Multidrug resistance in Gram-negative bacteria. Curr Opin Microbiol. 2001;4(5):500-508.

69. Davis BD, Dulbecco R, Eisen HN, Ginsberg HS, editors. Tratado de Microbiología. 4th ed. Barcelona, Spain: Masson S.A; 1996. p.198-219.

70. Domínguez E, Zarazaga M, Saenz Y, Brinas L, Torres C. Mechanisms of antibiotic resistance in Escherichia coli isolates obtained from healthy children in Spain. Microb Drug Resist. 2002;8(4):321-327.

71. Hogan D, Kolter R. Why are bacteria refractory to antimicrobials? Curr Opin Microbiol. 2002;5:472-477.

72. Sander CC, Sander WE. Resistance to antibacterial agent. In: Jung Kind DL, Mortensen JE, Fraimoro HS, Calandra GB, editors. Antimicrobial resistance: A crisis in health care. New York, NY: Plenum Press; 1995. p. 15-23.

73. Harbarth S, Albrich W, Brun-Buisson C. Outpatient antibiotic use and prevalence of antibiotic-resistant Pneumococci in France and Germany: a sociocultural perspective. Emerg Infect Dis. 2002;8(12):14601467

74. Drlica K. The mutant selection window and antimicrobial resistance. $J$ Antimicrob Chemother. 2003;52:11-17.

75. Zhao X, Drlica K. Restricting the selection of antibiotic-resistant mutant bacteria: measurement and potential use of the mutant selection window. J Infect Dis. 2002;185:561-565.

76. Drlica K. Antibiotic resistance: can we beat the bugs? DDT. 2001;6(14):714

77. Drlica K, Zhao X. Mutant selection window hypothesis updated. Clin Infect Dis. 2007;44(5):681-688. 
78. Kozyrskyj AL, Dahl ME, Chateau DG, Mazowita GB, Klassen TP, Law BJ. Evidence-based prescribing of antibiotics for children: role of socioeconomic status and physician characteristics. CMAJ. 2004;171(2):139-145.

79. Nicolle LE. Preventing infections in non-hospital settings: long-term care. Emerg Infect Dis. 2001;7(2):205-207.

80. Butler CC, Kinnersley P, Prout H, Rollnick S, Edwards A, Elwyn G. Antibiotics and shared decision-making in primary care. J Antimicrob Chemother. 2001;48:435-440.

81. Arias ML, Artavia J, González P, Monge R. Antimicrobial susceptibility pattern of Gram-negative bacterias isolated from enteral feeding. Rev Biomed. 2000;11(3):169-174.

82. Gómez-Barreto D, Calderón-Jaimes E, Rodríguez R, Espinosa ML, Juárez M. características clínico-microbiológicas de la meningitis por Streptococcus pneumoniae resistente a la penicilina. Salud Pública Mex. 1999;41(5):397-404.

83. Aloush V, Navon-Venezia S, Seigman-Igra Y, Cabili Sh, Carmeli Y. Multidrug-resistant Pseudomonas aeruginosa: risk factors and clinical impact. Antimicrob Agents Chemother. 2006;50(1):43-48.

84. Bartlett JG. Literatura Commentary by John G. Bartlett: Antibiotic resistance. 2007; [cited 2007 July 20]; [about 3 p.]. Available from: http://www.medscape.com.

85. Coenen S, Michiels B, Van Royen P, Van der Auwera JC, Denekens J. Antibiotics for coughing in general practice: a questionnaire study to quantify and condense the reasons for prescribing. BMC Fam Pract. 2002;3(16):1-10.

86. Linder JA, Singer DE, Stafford RS. Association between antibiotic prescribing and visit duration in adults with upper respiratory tract infections. Clin Ther. 2003;25:2419-2430.

87. Owens RC, Fraser GL, Stogsdill P. Antimicrobial stewardship programs as a means to optimize antimicrobial use. Pharmacotherapy. 2004;24(7):896-908.

88. Pedersen G, Schonheyder HC, Steffensen FH, Sorensen HT. Risk of resistance related to antibiotic use before admission in patients with community-acquired bacteraemia. J Antimicrob Chemother 1999;43:119-126.

89. Bauchner H, Simpson L, Chessare J. Changing physician behaviour. Leading articles. Arch Dis Child. 2001;84:459-462.

90. Antimicrobial resistance. World Health Organization. 2002; [cited 2005 Aug 24]; 194: [about 4 p.]. Available from: http://www.who. int/mediacentre/factsheets/fs194/en/print.html.

91. Arias IB, Meza AL. Resistencia antimicrobiana de Salmonella, Shigella y Vibrio cholerae, Perú 1997-2002. Rev Peru Med Exp Salud Publica. 2004;21(4):273-275.

92. Van Driel ML, De Shutter A, Deveugele M, et al. Cristianes T. Are sore throat patients who hope for antibiotics actually asking for pain relief? Ann Fam Med. 2006;4(6):494-499.

93. Metlay JP, Branas ChC, Fishman NO. Hospital-reported Pneumococcal susceptibility to penicillin. Emerg Infect Dis. 2004;10(1):54-59.

94. Balabanova Y, Fedorin I, Kuznetsov S, et al. Antimicrobial prescribing patterns for respiratory diseases including tuberculosis in Russia: a possible role in drug resistance? J Antimicrob Chemother. 2004;54:673-679.

95. Castro R. Sicología Médica en México: el último cuarto de siglo. Rev Mex Sociol. 2001;63(3):271-293.

96. Smith RD, Coast J. Antimicrobial resistance: a global response. Bull World Health Organ. 2002;80:126-133.

97. Kravits R. Measuring patients' expectations and requests. Ann Intern Med. 2001;134:881-888.

98. Matuz M, Benko R, Doro P, Hajdu E, Nagy G, Nagy E, Monnet DL, Soos G. Regional variations in community consumption of antibiotics in Hungary, 1996-2003. Br J Clin Pharmacol. 2005;61(1):96-100.

99. Wegener HC, Aarestrup FM, Jensen LG, Hammerum AM, Bager F. Use of antimicrobial growth promoters in food animals and Enterococcus faecium resistance to therapeutic antimicrobial drugs in Europe. Emerg Infect Dis. 1999;5(3):329-335.
100. Lovine NM, Blazer MJ. Antibiotics in animal feed and spread of resistant Campylobacter from poultry to humans. Emerg Infect Dis. 2004;10(6):1158-1159.

101. Angulo FJ, Nunnery JA, Bair HD. Antimicrobial resistance in zoonotic enteric pathogens. Rev Sci Tech Off Int Epiz. 2004;23(2):1-12.

102. Anderson AD, Nelson JM, Rossiter Sh, Angulo FJ. Public health consequences of use of antimicrobial agents in food animals in the United States. Microb Drug Resist. 2003;9:373-379.

103. Gerst J. Detección de la resistencia a los antibióticos con los sistemas Vitek y Vitek 2 de bioMérieux. In: Salvatierra-González R, Benguigui Y, editors. Resistencia antimicrobiana en las Américas: Magnitud del problema y su contención. Washington, DC: OPS/OMS; 2000. p. 12-23.

104. Dancer SJ. How antibiotics can make us sick: the less obvious adverse effects of antimicrobial chemotherapy. Lancet Infect Dis. 2004;4:611-619.

105. Cabello FC. Antibióticos y acuicultura en Chile: consecuencias para la salud humana y animal. Rev Med Chile. 2004;132:1001-1006.

106. Gay K, Baughman W, Millar Y, et al. The emergence of Streptococcus pneumoniae resistant to macrolide antimicrobial agents: a 6-year population-based assessment. J Infect Dis. 2000;182:1417-1424.

107. Zoutman DE, Ford BD. The relationship between hospital infection surveillance and control activities and antibiotic-resistant pathogen rates. Am J Infect Control. 2005;33(1):1-5.

108. Sifuentes-Osornio J y Donís-Hernández J. Las redes de estudio de la resistencia bacteriana ¿son realmente necesarias? In: SalvatierraGonzález R, Benguigui Y, editors. Resistencia antimicrobiana en las Américas: Magnitud del problema y su contención. Washington, DC: OPS/OMS; 2000. p. 8-11.

109. Sosa A. La alianza para el uso prudente de los antibióticos. Resistencia a los antibióticos en América Latina. In: Salvatierra-González R, Benguigui Y, editors. Resistencia antimicrobiana en las Américas: Magnitud del problema y su contención. Washington, DC: OPS/OMS; 2000. p. 258-260.

110. Breilh J. Nuevos conceptos y técnicas de Investigación. Guía pedagógica para un taller de metodología. Quito, Ecuador: Centro de Estudios y Asesoría en Salud; 1994. p. 19-57.

111. Avorn JL, Barrett JF, McEwen SA, O’Brien TF, Levy SB. Antibiotic resistance synthesis of recommendations by expert policy groups. Geneva, Switzerland; World Health Organization; 2001. p. 1-163

112. Madaras-Kelly K. Optimizing antibiotic use in hospitals: the role of population-based antibiotic surveillance in limiting antibiotic resistance. Pharmacotherapy. 2003;23(12):1627-1633.

113. Gleckman RA. Selected issues in antibiotic resistance. Infect Med. 2004;21(3):114-122.

114. Zaidi M, Sifuentes-Osornio J, Rolón AL, et al. Inadequate therapy and antibiotic resistance risk factors for mortality in the intensive care unit. Arch Med Res. 2002;33(3):290-294.

115. Gotfried MH. Epidemiology of clinically diagnosed communityacquired pneumonia in the primary care setting: results from the 1999-2000 respiratory surveillance program. Am J Med. 2001;111(9A):25S-29S.

116. Finkelstein JA, Davis RL, Dowell SF, et al. reducing antibiotic use in children: a randomized trial in 12 practices. Pediatrics. 2001;108(1):1-7.

117. Kollef MH. Inadequate antimicrobial treatment: an important determinant of outcome for hospitalized patients. Clin Infect Dis. 2000;31(Suppl 4):S131-S138.

118. Courvalin P. Antimicrobial drug resistance: "prediction is very difficult, especially about the future". Emerg Infect Dis. 2005;11(10): $1503-1506$

119. Andrés JC, Andrés NF, Fornos JA. Evaluación de la intervención farmacéutica sobre cumplimiento en terapia antibiótica. Seguim Farmacoter. 2004;2(2):97-102. 
